\title{
The influence of motivation and self-efficacy to technology on the online tutorial achievement of distance education students
}

\author{
Yos Sudarso and Ucu Rahayu \\ Faculty of Teacher Training and Education, Universitas Terbuka, 15418, Tangerang Selatan, Indonesia
}

\begin{abstract}
This paper discusses the results of research on the influence of motivation and self-efficacy to technology on the achievement of students participating online tutorial at study program of Civics Education, Universitas Terbuka, Indonesia. The aims of the study are to determine (1) the motivation level of distance education students, (2) ) the self-efficacy to technology level of distance education students, (3) the influence of motivation and self efficacy to technology on the online tutorial achievement of distance education students. This research method is descriptive qualitative. Sample of the study is 46 students who took online tutorial of the courses of Human Rights, Young Generation Coach, and Criminology and Delinquency of Adolescent at the academic year of 2015 semester two. The instrument used in this research is the motivation and self-efficacy questionnaire and online tutorial tasks. The result of the study showed that firstly, the students' motivation is at medium level, secondly, the students' self-efficacy to technology is at medium level. Thirdly, students' motivation and self-efficacy to technology influence on the online tutorial achievement of distance education students' .
\end{abstract}

Keywords: motivation, self-efficacy, distance education, civic education.

\section{INTRODUCTION}

At open distance education (ODL) system, students and instructors are not always at the same place of learning. The students physically separate from their instructors at the most of their time of learning process. It implies to the limitation of interaction among students and instructors. To overcome this problem, it is required an information and communication technology. Therefore, in distance learning environment, online tutorial is used as students' academic services that can reach learners and create the interaction among students and their instructors. ${ }^{1}$ However, some obstacles such as the skills of students and tutors to use the technology can be a barrier to the quality of online tutorials. ${ }^{2,3}$ Less skills of students in using technology particularly computer and internet encourages students to always maintain their motivation and self efficacy to technology.

Motivation is the process whereby goal directed activity is instigated and sustained. ${ }^{4}$ Learning motivation is an internal and external encouragement of students to

*Email Address: yoss@ecampus.ut.ac.id study so that students' behavior changes occured. Therefore, learning motivation is a driving force of students to learn something. ${ }^{5}$

At distance education environment, student motivation was significantly associated with participation rates, where students with high intrinsic motivation had higher participation rates than students with lower intrinsic motivation. ${ }^{6}$ Students who have higher interest tend to engage in online learning at a higher level ${ }^{7}$. Other study indicate that the intrinsic motivation of the students of online learning is greater than the students who learn face to face. This intrinsic motivation will affect student participation and retention in online learning ${ }^{8}$. Internal motivation or intrinsic motivation of students can influence student behavior in online discussions. Intrinsic motivation encourages students to be more proactive, persistent and energetic in doing tasks to achieve success in online learning. Several studies show that there are several conditions that support intrinsic motivation, for example feedback from friends during online discussion, feedback from instructor ${ }^{10}$ and a convenient online discussion structure for students to communicate and share the same tools ${ }^{11}$. In addition, the motivation of 
ODL students increases the number of successful learners completing their studies; giving motivation from the instructor to learners can improve the learner's selfconfidence $^{12}$. From several studies above can be concluded that the motivation of the learner influence on the success of the learners in their learning.

Self-efficacy is the belief of one's capability to organize and execute the action required to manage the prospective situation..$^{13}$ In other words self-efficacy is the confidence of someone to do something. Academic selfefficacy is personal judgment of one's capabilities to organized and execute courses of action to attain designated types of educational performance. ${ }^{14}$ In the other words, academic self-efficacy is a person's belief in his ability to organize and implement learning activities to achieve the designed learning outcomes. A person who has low self-efficacy in completing the task, he will avoid the job; while the capable person will be ready to finish the tasks. Someone who has high self-efficacy will work hard and last longer when faced difficulties. Self-efficacy also affects academic motivation, learning and achievement ${ }^{15}$.

There are four factors affecting students' self-efficacy, namely, performance accomplishments or mastery experiences, vicarious experiences, verbal or social persuasion, and physiological, or somatic and emotional state. ${ }^{13}$ Performance experience is the learner experience of achievement in the past. Vicarious experience is an individual observing by another individual. Vicarious experience obtained after observing the success of others or through social models. Social persuasion is a way of strengthening people beliefs that they have what it takes to success, the enhances self-efficacy may become more permanent. Poor emotional condition such as stress and anxiety can reduce a person's self-efficacy.

Several studies have shown a relevancy between motivation and self-efficacy. ${ }^{16,17}$ When students have high motivation, they will have self-efficacy to technology and high level satisfaction of online learning as well, which will ultimately get high learning results as well. ${ }^{16}$ Students' motivation and self-efficacy affect their learning process, particularly, in the courses using computer technology. ${ }^{17}$

Based on several studies, student learning outcomes influenced by motivation ${ }^{18-21}$ and self-efficacy ${ }^{22-25}$. However, the influence of students' motivation and selfefficacy to technology on online tutorial achievement of open and distance students has not been much studied. Therefore, this paper will discuss the results of research on the influence of students' motivation and self-efficacy to technology on online tutorial achievements of ODL students particularly who follow the online tutorial of three courses in Universitas Terbuka, Indonesia. This study also examine the level motivation of the students, the level of self-efficacy of the students, and the level motivation and self-efficacy of the students based on gender.

\section{METHODE}

The design of this research is descriptive quantitative. The sample of the study are the students of Civics Education study program following online tutorial of (16 students). The research was conducted in South Tangerang, Banten Province, Indonesia from February to October 2015. The instruments used in this research are motivation and self-efficacy questionnaire by using Likert scale, and final score of tutorial assignment (score). Data of students' motivation were collected by using motivation questionnaire. The data of students' selfefficacy were collected through self-efficacy questionnaire. The students' achievements were collected from the score of online tutorial students of three courses: Human Rights, Criminology and Delinquency of Youth and Young Generation. Then, the data was analyzed by SPSS to find the correlation between students' motivation and the achievement of online tutorial students; the correlation between students' self-efficacy to technology and the achievement of online tutorial students, and the correlation between students' motivation, students' selfefficacy and the achievement of online tutorial students.

\section{RESULT AND DISCUSSION}

\section{The level of students' motivation and its relation to the achievement of online tutorial students}

The result showed that based on its category, $52 \%$ of students are in high level motivation, $44 \%$ are medium level motivation, and $4 \%$ are low level motivation. It means that more than fifty percent of Civics Education students have high motivation in learning. However, the average motivation of Civics Education students is 45.37 (SD 5.55). It is at medium level category. Motivation level category of the students can be seen at the Figure 1 below.

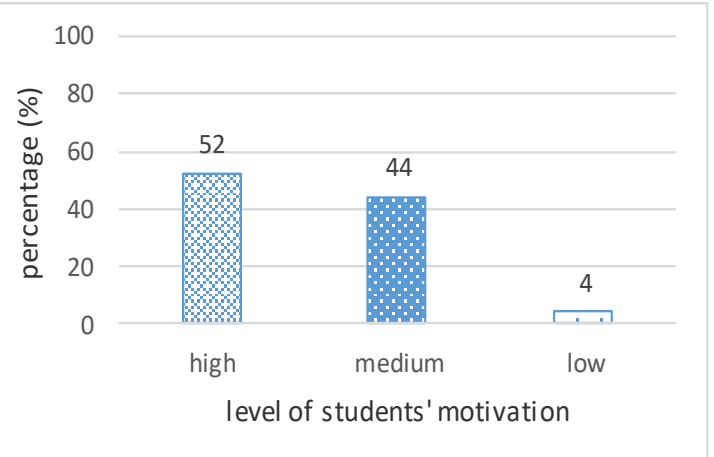

Fig.1. The level of students' motivation

The motivation level of Civic Education students of Universitas Terbuka is not as high as motivation level of Biology Education students of Universitas Terbuka. Motivation level of Biology education students is $69 \% .{ }^{26} \mathrm{It}$ showed that even though these study programs have similar characteristics such as in-service teacher students, the students' age range around 30 to 55 years old, under 
coordination of faculty of teacher training and education at Universitas Terbuka Indonesia, but they have different motivation level. It is possibly caused by

Statistically, there is no significant difference between the motivation of male and female students, even though female students' motivation is higher than male students. It is relevant to the other study that there are differences of intrinsic motivation between male students and female students in South Africa. ${ }^{27}$ This is because male students have greater responsibilities than female students either at work or at home or in the neighborhood. This condition might encourage male students to complete their studies faster and achieve better achievements.

The mean of online tutorial score for the subjects of Human Rights, Young Generation Development, and Criminology and Delinquency of Youth is 57.78 (SD 10.765). After analyzed statistically, the relationship of motivation to the achievement of online tutorial students is at $r=0,694$. It means that the correlation between students' motivation and students' achievement at high level.

This means that the higher the motivation of the student has, the higher the achievement of the online tutorial achieved by the student. This is in line with other study that the motivation of the learner influences on the success of the learner in learning. ${ }^{12} \mathrm{We}$ are agree that motivation to learn is the energy / driving force of students in learning. ${ }^{15}$ The correlation between the students' motivation with the students' score of online tutorial can be seen in the following figure.

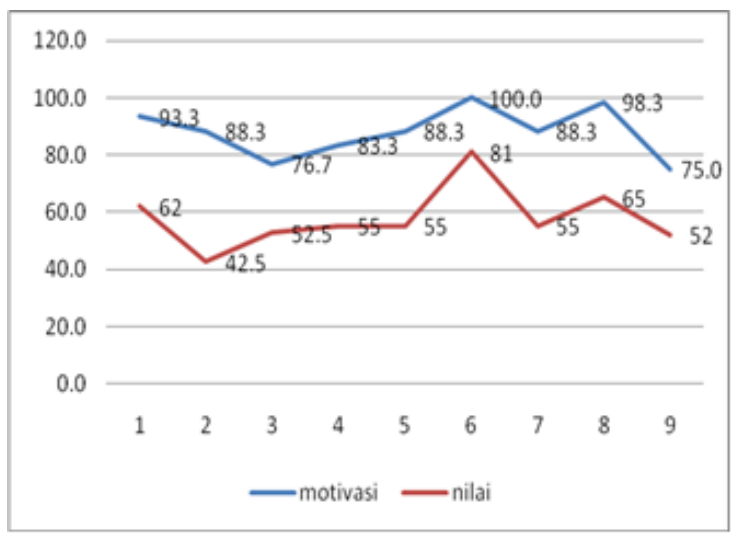

Fig.2. The graph of students' motivation and online tutorial achievement.

The level of students' self-efficacy to technology and its relation to the achievement of online tutorial students

Based on the level category, there are $41 \%$ of students have high self-efficacy, $55 \%$ have moderate selfefficacy, and $4 \%$ of students have low self-efficacy. The average self-efficacy of Civics Education students is 37.78 (SD 4,58). Therefore, the mean self-efficacy of Civic Education students is at a moderate level. Selfefficacy level of the students can be seen at the Figure 3 below.

Self-efficacy of Civics education students is lower than its Biology education students. Self-efficacy of Biology Education students is about $63 \% .^{22}$ Self efficacy of Civic education students is lower than its biology education, might due to skills on operating computer of biology education students are better. Furthermore, there is a significant difference between the self-efficacy of male and female students. Self-efficacy of male students is significantly higher than female students. It is relevant to the results of a study that there is a significant difference between the self-efficacy of male and female students in Albania. ${ }^{28}$

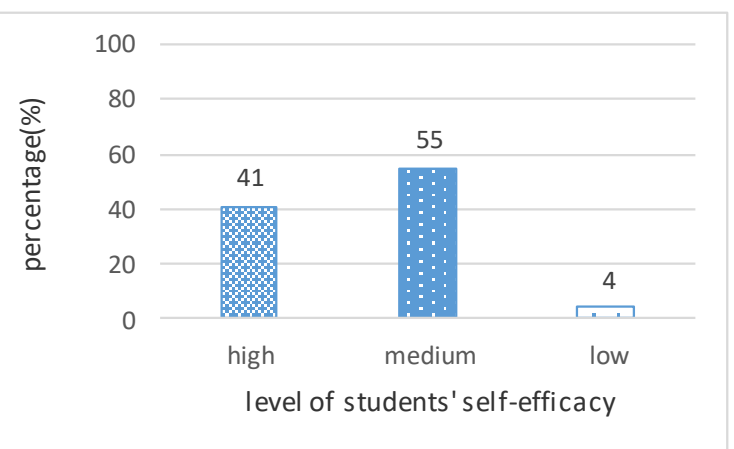

Fig.3. The level of students' self-efficacy

After analyzed statistically, the relationship between self-efficacy with the final score of the online tutorials get the correlation coefficient $(r)=0.566$ or at medium level. It means that correlation between self-efficacy with the score of online tutorial is at medium level. This is in line with the opinion that self-efficacy affects achievement. ${ }^{15}$ Since self-efficacy is a person's belief in his ability to organize and implement learning activities to achieve the learning outcomes designed. ${ }^{14}$ Its can be seen in the following figure.

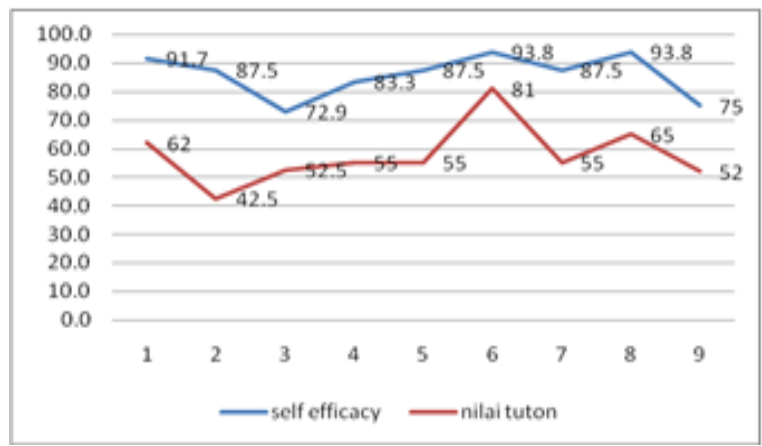

Fig.4. The graph of students' self-efficacy and achievement of students' online tutorial

\section{The correlation of students' motivation, students' self efficacy, and students' achievement}

The correlation between students' motivation, selfefficacy and achievement of online tutorial is also analyzed. The result showed that there is correlation among students' motivation, self-efficacy and achievement of online tutorial at $r=0.825$ or at very strong relationship. This is in line with previous studies which suggest that there is a correlation between motivation and self-efficacy. Self-efficacy affects the academic motivation of a person and is closely related to the intrinsic level of interest in performing tasks. In addition, self-efficacy plays a role in maintaining 
motivation and achievement of academic achievement. ${ }^{14}$ Furthermore, the other study proved that when a person has a high motivation, he will have self-efficacy to technology and the level of online learning satisfaction is high too, which will ultimately get high learning results as well. ${ }^{16}$

\section{CONCLUSIONS}

Based on the research results can be concluded as follows.

1. The average motivation of Civics Education student is at a moderate level, where the motivation of male students is higher but not significantly compared to female students. Motivation has correlation to online tutorial scores.

2. The average self-efficacy of Civics Education students is at moderate level, where self-efficacy of male students is significantly higher than female students. Self-efficacy has a less powerful effect on online tutorial scores

3. Motivation and self-efficacy have a significant correlation in improving online tutorial learning outcomes.

\section{REFERENCES}

[1] Tian Belawati dkk, 2009

[2] Siti Juleha and Yulia Budiawati, 2013,

[3] Yulia Budiwati 2007

[4] Schunk, Pintrich and Meece

[5] Uno, Hamzah, B. Teori motivasi \& pengukurannya: Analisis di bidang pendidikan. Jakarta: Bumi Aksara. (2014).

[6] K. Xie, V.A Durrington. \& L.L Yen. Relationship between students' motivation and their participation in asynchronous online discussion. Journal of Online Learning and Teaching, 7(1) (2011) 17-29

[7] C. Sansone, T. Faughton, J.L. Zachary, J. Butner, and C. Heiner, Self-regulation of motivation when learning online: the impotance of who, why, and how. Education Tech Research Development, 59 (2011) 199-212

[8] Margareth Katherine Hartnet. Motivation to learn in online environments: an exploration of two tertiary education context (Doctoral thesis). Masey university, Palmerston North, New Zealand. 2010 Http://muir.massey.ac.nz/handle/10179/2043

[9] Kui Xie. What do the number say? The influence of motivation and peer feedback on students' behavior in online discussion. British Journal of Educational Technology, 44(2) (2013) 288-301

[10] Ucu Rahayu

[11] R.H. Shroff and D.R. Vogel. Assessing the factors deemed to support individual students' intrinsic motivation in technology supported online and face to face discussions. Journal of Information Technology Education 8: (2009)

[12] L. Visser, T. Plomp, R.J. Amirault, W. Kuiper.
Motivating studens at distance: the case of international audience. Educational Technology Research Development, 50(2) (2002), 94-100.

[13] A Bandura. Self-efficacy: the exercise of control. New York: Freeman Press (1997).

[14] B.J. Zimmerman, Self-efficacy: an essential motive to learn. Contemporary Educational Psychology, 25 (2000) 82-91.

[15] D.H. Schunk \& F. Pajares. The development of academic self-efficacy. In A. Wigfield \& J.S Eccle (Eds), Development of achievement motivation San Diego, CA: Academic Press. (2002)

[16] C.H. Wang, D.M. Shannon, M.E. Ross. Students' characteristics, self-regulated learning, technology self-efficacy, and course outcome in online learning. Distance Education 34(3)(2013) 302-323

[17] Mahmud bin Abd Haji Wahab. Study on the impact of motivation, efikasi diri, and learning strategies of faculty of education undergraduate studying ICT courses. The Journal of Behavioural Science, 2 (1) (2007) 151- 185

[18] Glenda C. Rakes, Karee E. Dunn. Journal of Interactive Online Learning, 9(1)(2010) 78-93.

[19] Oriahi Christiana. Influence of motivating on students' academic performance. The Social Sciences, 4(1)(2009) 30-36.

[20] Addejia Tella. The impact of motivation on student's achievement and learning outcomes in mathematics among secondary school students in Nigeria. Eurasia Journal of Mathematics, Science \& Technology Education, 3(2)(2007) 149-156

[21] Maria de Fatima G. The relationship between selfefficacy and academic achievement in adults' learner. Athens Journal of Education, 1(3)(2014) 237-246

[22] Patrick C. Lee and Zhenxing Mao. The relation among self-efficacy, learning approaches, and academic performance: an exploratory study. Journal of teaching in Travel \& Tourism, 16(3) (2016) 178194.

[23] Jo Tilton and Maggie Hartnett. What are the influence on teacher mobile technology self-efficacy in secondary school classrooms? Journal of Open, Flexible, and Distance Learning, 20 (2)(2016) 79-93.

[24] De Ture. Cognitive style and self-efficacy: Predicting students' success in online distance education. The American Journal of Distance Education, 18(1)(2004) 21-38

[25] M. Puzziferro, Online technology self-efficacy and self-regulated learning as predictor of final grade and satisfaction in college level online course. The American Journal of Distance Education, 22 (2008) 72-89.

[26] Ucu Rahayu and Ari Widodo. The profile of Biology Education Students, Universitas Terbuka, on selfregulated learning. Proceeding of International Seminar on Mathematics, Science, and Computer Science Education. ISBN 987-602-95549-2-2 (2015) 
[27] Hungi Ongowo. Motivational belief. And self regulation in biology learning: influence of ethnicity, gender and grade level. Creative Education, 5(2014) 218-227

[28] Rudina Shkullaku. The relationship between self efficacy and academic performance in the context of gender among Albanian student. European Academic Research 1(4)(2012) 467-478 